\title{
“I don't know what I am doing!": Surfacing struggles of managerial identity work
}

\begin{abstract}
Recent work contends that management education provides an important space for managers' identity work. However, it is also recognised that much of what is currently offered constrains rather than enables managers' identity work. Against this background, I present material which provides important practical possibilities to managers for more realistic and helpful forms of identity work, and theoretically also add to the development of a more nuanced understanding of managerial identity work processes. Drawing on interviews with a range of managers, I offer rare empirical evidence which illustrates the ordinarily suppressed emotional struggles of the mismatch between social identities of manager and self identities. In this way, I contribute to current theoretical offerings to demonstrate the centrality of emotions to processes of becoming. In turn, I propose that exploration of these emotions offers management educators important possibilities for facilitating managers' identity work.
\end{abstract}

Key words: emotion; identity work; management education 


\section{Introduction}

Recent work proposes that management education provides an important space for managers' identity work (Petriglieri and Petriglieri, 2010; Warhurst, 2011). However, it is also recognised that much of what is currently offered constrains rather than enables managers' identity work since it presents a sanitised perspective which avoids the complexities of the lived experiences of managers. In so doing, an idealised image of management work is elevated (Grey, 2007). Drawing upon interview data, this paper contributes by offering empirical material which provides unusual glimpses into the lived experiences of managers which presents important practical possibilities to managers for more realistic and helpful identity work. Theoretically it also adds to the development of a more nuanced understanding of managerial identity work. Specifically, in response to calls for empirical studies of identity work processes (Alvesson et al; 2008; Sveningsson and Alvesson, 2003), the paper illuminates the emotional struggles of managerial identity work. These are speculated to result from a mismatch between self understandings and social identities of the managerial role promoted by discourse (Alvesson et al., 2008). While theoretically significant, these struggles are challenging to reveal empirically given difficulties in overcoming the staged performance of positive identity talk, typical of managers (Ybema et al., 2009).

I propose that the surfacing of these struggles reveals the centrality of emotions to processes of becoming and presents important possibilities for enriched input into managerial identity work in management education. At a personal level, it can help managers to cope better with their identity work since many managers are likely to experience similar struggles and much could be achieved in the airing of these 
concerns, if not at least to facilitate an appreciation of their shared nature. Further, the recognition of the emotions inherent in managerial identity work presents opportunities for questioning accepted ways of making sense of the world (Cunliffe, 2002) and invites possibilities for new knowledge and action in practice which acknowledge the limitations of what managers can be.

The paper is structured as follows. Firstly, drawing on the work of Watson (2008), I outline my conception of identity work particularly exploring the ways in which managerial discourse informs socially available managerial identities. I suggest that given the grand claims of managerial discourse, socially available notions of managerial identity present high expectations for what it means to be a manager. I argue that this provides for an emotionally charged process of identity work where the manager works to achieve a personal self identity which is influenced by and negotiated with demanding socially available managerial identities. To illustrate these claims, I draw on interview data with a range of managers to highlight the emotional aspects of managerial identity work which are frequently silenced. Crucially, these were raised by managers themselves. Finally, I consider the implications of these struggles for our understandings of identity work and for management education.

\section{Discourse and Identity}

Discourse is recognised as playing an important role in shaping human beings' notion of who and what they are (Alvesson and Willmott, 2002; Knights and Willmott, 1989, Mumby and Chair, 1997). As defined by Watson (2001a: 113) discourse is "a connected set of statements, concepts, terms and expressions which constitutes a way 
of talking or writing about a particular issue, thus framing the way people understand and act with respect to that issue". Critically it provides a set of "resources that enable us to see and speak of the world in particular ways...creates a sense of belonging for the discourse public... and a limited range of identities that can be adopted by those who share that sense of belonging" (Fulop et al., 2009: 694). The privileging of particular ways of seeing, speaking and being thus reveals an important 'power/knowledge' (Foucault, 1980) which works to give voice to certain ideas whilst silencing others. Consequently, dominant discourses emerge from this process.

With respect to management, dominant discourses originate from the wider modernism project (Watson, 2005). Central to modernism is the application of rational analysis to social, political and economic affairs with the aim of achieving greater control over the world and the progression of humankind generally. As Kerfoot and Knights (1998) observe this type of thinking reveals a form of masculinity which seeks 'to master all'. Accordingly, managerial discourses construct management as a task which requires the application of expertise and rational analysis to provide control over organisational activity and ultimately the realisation of organisational goals.

Whilst various discourses emerge and compete for managerial attention over time (Du Gay et al 1996), the majority remain faithful to the overarching aims of the modernist ideal. For example, contemporary discourses, notably entrepreneurial discourse which emphasises initiative, autonomy and responsibility (Du Gay et al, 1996) and leadership discourse which recasts managers as leaders (Ford and Harding, 2007), arguably amplify the aims of the modernist project. As such, it is recognised that 
much managerial discourse can be described as 'grandiose' (Sveningsson and Alvesson, 2003). For example, leadership discourse is replete with suggestions of management as saviours of organisations tasked with the responsibility of ensuring survival (Meindl et al, 1985; Rost, 1991).

In turn, available managerial discourses offer the raw material for managerial identity work. Watson (2008:129) contends that "elements of discourse are personified in the form of 'social-identities' in a way which makes them meaningful, accessible and appealing or unappealing to the individual, and in a way that the abstractions of a 'discourse' could not". This posits social identities as focal elements within discourses to which people refer in their identity work. Social identities are thus "cultural, discursive or institutional notions of who or what any individual might be" (Watson 2008: 131).

In the light of grandiose managerial discourse, it is unsurprising that research suggests that in taking on the social identity of 'manager', individuals typically represent themselves as rational actors who are in control and who employ analytical skills in order to implement strategies in pursuit of organisational goals (Sims, 2003; Watson, 2001a). Such representations highlight important aspects of common understandings of what a manager is taken to be. First, a manager is seen as one who secures control over organisational events seemingly minimising uncertainty and ambiguity (Gabriel, 1999; Watson, 2002). Second, a manager is one who is skilful and knowledgeable applying her expertise to organisational troubles (Hill, 1992, Parker, 2004). Managers are turned to for answers and are expected to be right. As Goffman (1967) suggests, central to the position of authority is that 'you know everything'. Third, given the 
expert status, it follows that a manager is also one who is confident (Parker, 2004; Sturdy et al, 2006). Fourth, a manager is goal oriented (Fineman, 1993) and works to guarantee successful task completion (Jackall, 1988). Fifth, professionalism and the suppression of emotion are implicit to a managerial identity (Ogbonna and Harris, 2004; Parkin, 1993). Whilst this list is by no means exhaustive, it highlights key facets of widespread notions of 'manager' and taken together, it follows that to be a manager is "in many people's eyes, (is) to be recognised as a person of some consequence" (Grey 2007: 46).

Grey's assertion highlights that grandiose managerial discourse generates rather lofty ideas of what a manager might be. Others have problematised dominant ideals which emanate from such discourse (Kerfoot and Knights, 1998; Willmott, 1984), and some have taken this further by beginning to empirically investigate the ways in which this "plays out in the work worlds of the individuals facing them" (Sveningsson and Alvesson, 2003: 1169). The current study seeks to add to empirical work in considering the ways in which demanding social identities of manager are mobilised in the identity work of managers. Furthermore, as the analysis will highlight, efforts to reconcile social and self identities gives rise to uncomfortable struggles, as such, this work elaborates emotional aspects of current understandings of identity work. Accordingly, I now turn to a discussion of the ways in which social identities inform identity work. 


\section{Identity Work}

External social identities of 'manager' inform an individual's self identity defined as "the individual's own notion of who and what they are" (Watson, 2008:131). As Watson (2008: 129) elaborates "the crux of the matter is the extent to which people embrace particular social identities or 'personas' as elements of their self identity". Social identities thus provide input into processes of identity work, defined by Sveningsson and Alvesson (2003: 1165) as, engagement in "forming, repairing, maintaining or strengthening or revising constructions that are productive of a sense of coherence and distinctiveness". An emphasis upon identity work highlights the ongoing and constructed quality of identity (Ashforth, 1998), and recognises that individuals are not passive recipients of external social identities (Collinson, 2003; Warhurst, 2011). Rather they can and do "interpret or even modify the role given to them in the 'script' of any given social identity" (Watson, 2008: 129). Nevertheless, individuals' self identities are also powerfully constrained by available social identities (Somers, 1994; Watson, 2008). As Reedy (2009:104) contends "choice is a possibility but determinism is a probability".

The above discussion highlights that identity work involves a "conversation or negotiation between internal ideas, wishes and affections and external images and evaluations" (Ybema, et al, 2009: 303) and underlines the struggles inherent to identity work (Jenkins, 1996; Sveningsson and Alvesson, 2003). Such struggles relate to a number of factors. In part, struggle relates to choices individuals must make between competing social identities and discourses (Clarke et al, 2009; Sveningsson and Alvesson, 2003; Thomas and Linstead, 2002). Such competition contributes to the 
ongoing challenge of the identity project- identity work is never complete (Knights and Vurdubakis, 1994; Ashforth, 1998). Further, struggle follows from the limits of available social identities and discourses (Watson, 2008), in other words 'who' we can 'be' is heavily influenced by discursive resources which are permitted by society (Bruner, 1990; Somers, 1994). It is suggested that in the case of the manager, this aspect of struggle is particularly significant but remains under explored.

Permitted social identities of what it means to be a manager generate a set of demanding expectations of how one ought to be as a manager. As discussed above, dominant managerial identities set up expectations that the manager is amongst other things, one who ought to be in control, right, and knowledgeable. Given such demanding expectations, it is speculated that an important issue for managers is a felt discrepancy between the ideals of the managerial social identity and personal identity (Alvesson et al., 2008). This is consistent with Elsbach (1999) who highlights the significance of conflict to identification processes. It is suggested that this discrepancy induces considerable uncomfortable emotion which has so far been insufficiently recognised. Ironically, available social identities of manager ensure these emotions are typically silenced. Indeed, Clarke et al (2009) revealed how managers who displayed emotion were portrayed as 'weak' or 'pink and fluffy'.

A small number of studies however provide some insight into these struggles. Parker's (2004) autobiographical account of his 'becoming manager' highlights a disparity between expectations of what a manager ought to be and his personal identity, "they would all look at me in a faintly disappointed way, having expected something like leadership to light up the room. They expected me to be confident and 
knowledgeable, and I was... still just me, when I needed to become a manager" (p.47). Similarly, Watson's (2001a) ethnographic study evidences this disparity in what he terms a 'double control problem' where managers work to manage the self whilst simultaneously being expected to be other to manage the activities and thinking of colleagues. Moreover, research suggests that considerable unease follows this conflict. Jackall (1998) and Vince (2001) highlight the significant anxiety associated with measuring up to the expectations of success associated with the managerial identity. Vince (2001:1339) for example suggests that expectations "to be successful, always right and stay in control" meant that the managers in his study "lived with considerable anxiety about not achieving what one imagines one ought to achieve". The work of Mischenko (2005) further documents the frustration and anger which results from the expectation of the manager to 'always be in control, always calm' (p.208)

Yet ironically, whilst the expectations of the managerial identity foster uncomfortable emotion, they also deny its expression. As Hill (1992: 199) offers, the managers she studied had to be "careful in expressing anger, anxiety and frustration, portraying maturity and professionalism and a sense of serenity. Be like a duck- on the surface calm and serene and underneath paddle like hell". The denial of emotion thus often requires managers to engage in significant emotional labour (Hoschild, 1983). Indeed, this is vividly illustrated by a participant in Costas and Fleming's (2009) study "it is like you are at a masquerade party and you come to the party every day and choose a mask to wear. And you wear that mask everyday and you return it at the end of the day". Moreover, the literature documents the negative impact of such masquerade (Ashforth and Humphrey, 1993; Bono and Vey, 2005). However, to date, the 
emotional work undertaken by managers' remains under acknowledged (Clarke et al, 2007). If it is considered at all, discussion is limited to the ways in which emotion can be managed for organisational benefit (Brotheridge and Lee, 2008; Humphrey et al, 2008).

Against this background, I seek to illuminate further the often silenced struggles of managerial identity work. Specifically, I draw attention to the emotional challenges presented by disparities between the ideals of the managerial social identity and self identity. In so doing, I begin to respond to calls from Sturdy et al (2006) for empirical consideration of emotional aspects of identity work. Whilst others have suggested the importance of these struggles, they are rarely considered as central to discussion, as Ybema et al (2009: 312) observe few studies privilege the "subtleties of indecisive, insecure, critical or self depreciative identity talk". Moreover, the surfacing of these struggles offers important implications for facilitating managers' identity work in management education.

\section{The Research}

The data emerged from in-depth interviews in a research project whose primary focus was on understanding the ways in which MBA learning informed management practice and careers (Author, 2006; 2008). The approach taken in this study sought to understand this formal learning within the broader context of informal manager learning, and it was discussions of this context which provided insights into the struggles of managerial identity work. Thus the data presented emerged as an unintended research outcome. However, the lack of intentionality is not seen as 
problematic and may be necessary to uncover these struggles. As Ybema et al (2009) observe, methodologically researchers are challenged to overcome the staged performance of a positive self identity to reveal ambiguous, indecisive and negative identity talk. I cannot be certain why the managers here were able to engage in such negative identity talk but it is likely that their willingness to 'open up' was influenced by my identity as a young female researcher. Indeed, the literature acknowledges the ways in which a variety of social attributes influence qualitative data production (Broom et al., 2009). Moreover, their choice to disclose their struggles is also likely to reflect the way in which the interview method is especially helpful for providing space for individuals to unveil issues of personal importance (Barley and Kunda, 2001). Here, the semi-structured interviews gave managers opportunities to shape conversation and as rapport developed, managers revealed the struggles upon which this article is based. Whilst interview data is subject to limitations, it does offer important insights which future, more intensive research can develop.

The data drawn upon is taken from interviews with 35 UK MBA alumni, 19 males and 16 females aged between 29 and 56 years old, who held a range of managerial positions spanning private, public and voluntary organisations. The sample included individuals with a range of managerial experience in terms of years of service and organisational position as well as occupational expertise. Each interview lasted between 1 and 2 hours, and asked managers to describe their careers to date, the challenges of their current role, their manager learning generally and their MBA learning in particular. All interviews were recorded and transcribed. 
The study adopted an interpretive research approach whose goal as described by Schwandt (1994: 118) is "to understand the complex world of lived experience from the point of view of those who live it". This broad approach embodies a number of competing paradigms but in line with discussions of identity work processes described above it is the social constructionist position which is adopted here. This contends that our reality is determined by the way in which we experience and understand the world which we construct and reconstruct for ourselves in interaction with others (Berger and Luckmann, 1996). To adopt such a position requires an acceptance of the ways in which the researcher interacts with the researched to jointly shape the constructions of each other. Thus my constructions of managers' identity work struggles emerged through an iterative process of research and analysis consistent with a grounded theory approach (Strauss and Corbin, 1998) where interviews were conducted in parallel with the analysis. As the initial interviews progressed, I was struck by discussions which highlighted the tensions managers experienced in their learning to 'become managers'. In subsequent interviews, I therefore sought to develop this emergent theme by probing managers if such tensions arose. The analysis followed guidelines developed by Strauss and Corbin (1998) and involved an iterative process of travelling between transcripts and the emerging structure. The process began by reading and re-reading transcripts, allowing provisional categories to emerge. As the analysis progressed, categories were consolidated and organised taking account of frequency and saliency as well as the development of the emerging structure (Ritchie and Spencer, 1994). Finally, informed by Watson (2008), categories were integrated around the central notion of struggles associated with negotiations between socially available managerial identities and self identities. The discussion that follows highlights these typically silenced struggles of 
becoming a manager, drawing attention to the uncomfortable emotions associated with this endeavour which the analysis revealed as especially significant. In line with the constructionist stance taken, it is acknowledged that the interpretation offered is of course my "construction of the constructions of the actors one studies" (Schwandt, 1994:118).

\section{Findings}

\section{Being made manager}

Individuals' descriptions of their learning to be a manager suggested that living up to the expectations of the role were often most acute when taking up the formal position. Indeed, it is recognised that identity work is heightened at times of transition (Ibarra, 1999). Notably, the accounts suggested a particular tension between individuals' understandings of who they needed to be as a manager and who they felt to be:

"This is talking from bitter experience, when I first got made manager, they give you the title, 'you are a manager, carry on'. The only difference in training to be a manager between the Friday and the Monday was I had a different car park pass. You are a manager. They just assumed you could do it. So you have got no support which meant that you were managing badly because you don't know what you are doing, you are making it up as you go along which also means that you don't have a lot of confidence in your role or your abilities to do it. " [Finance Manager, male, age 35] 
The example highlights a felt discrepancy between the social identity of manager and the individual's notion of who he is. Quite clearly he is unsure of how to be a manager and his identity work is complicated by the assumption that the title of manager is synonymous with 'being' manager. The identity literature recognises that managerial identity is emergent and there is no obvious point when one 'becomes a manager' (Watson, 2001b), yet the example illustrates that this emergence is ignored by organisations making for a 'bitter' process of managerial becoming.

Others' descriptions of their transitions into managerial roles suggested similarly that their identity work involved significant uncomfortable emotion:

"When you first go into a managing role, you are quite nervous by the whole process of leading people and think 'I am not going to be very good at this'. But I think sometimes you do have to stretch yourself because when I came into this position, I felt out of my depth and it probably took, two or three months to structure things in my head, that I can do this and I have been picked because they think I can do it" [Logistics Leader, female, age 32]

The example is illustrative of the conversation of identity work described by Ybema et al (2009) where the individual can be seen to be negotiating the demands of the social identity of manager against internal ideas of personal capabilities. Given the lofty demands that make up the managerial role, this negotiation evokes feelings of nervousness, self doubt and feeling out of one's depth. Further, the account suggests that working on one's managerial identity is an on-going project and is consistent with a processual understanding of identity work (Ashforth, 1998). Indeed, whilst the 
struggles of identity work were more pronounced upon taking the position of manager, discussions highlighted that ongoing tensions of working on a managerial identity were fuelled by the everyday challenges of the role.

\section{I don't know what I am doing!}

A significant challenge expressed by a number of managers centred upon fulfilling the expectation that a manager is somebody who knows:

"There are also other challenges where colleagues look to me for direction and I don't know! They are looking at me and I don't know! So it puts a bit of pressure on you because how you can help other people... I think deep down you do have some ideas... because it is very easy to be a bit scared and say 'I don't know what I am doing at all here!"' [Training Manager, male, age 41]

"I have learned that I am quite a stoic person. Myself, I have had issues and concerns alongside the other people and I didn't have the answers, and I am trying to support other people when myself I don't know what is going on". [Management Accountant, female, age 38]

The accounts illustrate the tensions managers experience in assuming the social identity of manager as somebody who knows against a private identity of somebody who doesn't know. The discrepancy between expectations of the managerial role and personal notions of self thus generates pressure and fear, again illustrating the significant emotion involved in managerial identity work. Of interest, as the latter 
quote suggests, the necessary silencing of these fears over time shaped aspects of personal identity where the individual developed a perception of herself as a "stoic person". Others however expressed greater difficulties in suffering hardship without showing emotion:

"Probably the thing that I find most difficult is when I feel under pressure, to try and maintain a sort of enthusiasm that I can pass onto others...I am facing difficulties myself with handling my side of it but you have really got to try and put that to one side. I do find that difficult. Almost having to be a bit Jekyll and Hyde" [Training Services Manager, male, age 56]

This discrepancy can be seen as symptomatic of Watson's (2001) 'double control problem'. Indeed, for the managers here, being accountable for themselves was often trouble enough as a recurring theme was a reference to struggles with self confidence.

\section{I have never been confident}

The interviews revealed that a significant aspect of working on the identity of manager was an attempt to improve self confidence:

"Self confidence has had to improve, outwardly anyway". [Operations Manager, male, age 35]

This suggests that individuals acknowledged self confidence as a key dimension of the social identity of manager and is consistent with Sturdy et al's (2006) assertion 
that self confidence is an important but neglected issue in understandings of managers' identity work. However, as indicated here, this was often at odds with a private self identity of somebody who lacked confidence:

"I have never had a great deal of confidence, I have had to do things and people might say I have got self confidence but I don't feel that I have." [Research Team Manager, female, age 39]

Both of these comments portray a belief that others might be tricked by a fragile confident identity. However, in contrast to Sturdy et al's (2006) position that self deception follows, for many managers here, this did not silence internal struggles which challenged the individual to become more confident as a manager:

"I have never been confident. And I would say even now I am not. No reason why I shouldn't be, I know more than most people I am presenting to, very senior managers. But I always tend to struggle sometimes with confidence. I think it is just because if you are conscientious and dedicated, then there is always that doubt that you have not done a good job or it is not perfect." [Product Manager, female, age 38]

This illustration documents a degree of angst in the ongoing negotiation between the expectations of confidence of the managerial role and a self identity as somebody who 'has never been confident'. In part this relates to her perceived self identity as a 'conscientious and dedicated' person striving for perfection but there is also a suggestion that the anxiety is fuelled by the expectation of the manager as somebody who knows. Whilst she states that she 'knows more than most people I am presenting 
to', there is a suggestion that knowing is incomplete which informs the struggle. Of course, knowing is never complete but the expectation of the expert manager nevertheless pressures the identity work of managers to be the knower. To be seen as somebody who does not know and hence might be wrong challenges the expectation that the manager is one who is in control and always right.

\section{You are a manager, why don't you know that?}

The pressure for managers to 'get it right' was a recurrent theme in managers' identity work. Even when managers had held formal positions for a number of years, their accounts suggested that tensions remained between a social identity of one who is right and successful, and a private identity of one who is wrong and fails. This tension seemed particularly marked when faced with new managerial challenges.

"It is doing something that I have never done before; it feels quite daunting because it will be very obvious whether you have done a good job... I think the challenge is that we have to get it right, and with all the continual changes getting it right is a bit of a moving bus. And that does worry me a little bit but you have to think would anybody else be doing it differently? It could make or break your career really." [Logistics Leader, female, age 32]

The account illustrates the ways in which the expectation of the social identity of manager as one who gets it right, generates notable fear and worry for the individual. Indeed, reflecting observations by Jackall (1988), getting it wrong can be seen to 'break your career', suggesting one who is wrong can no longer be seen as a 
'manager'. Unsurprisingly the fear associated with being wrong is fuelled by ongoing change which limits individual control over the situation. However, again this is incompatible with the social identity of manager as one who is in control. The excerpt suggests that the social identity of manager is rather unforgiving. Ultimately one is judged by results alone which in the case of the manager are often "very obvious" and such visibility heightens fear of failure. Furthermore, the accounts suggested that measuring up to the expectation to be right was also associated with significant frustration and self doubt:

"I felt very, very frustrated. And for a person like me who is quite impulsive, action orientated, patience is not something I possess. I beat myself up about it a lot, I thought it was me, I thought I had failed, I thought I was crap. I went through a whole 'oh my God what the hell am I doing here?' At that point I thought I just want to go back to where you can have a joke about what happened on Eastenders. I thought how do I get out of this situation and get back to something I am familiar with? And it took me a while to say 'no, you have got to learn from this'”' [Trading Director, female, age 37]

The account which details the individual's difficulties in taking up a new responsibility of managing an international team, highlights the significant pressure of those in managerial positions to not only be right but to be successful immediately. Moreover, her comments indicate that the problems encountered primarily challenged aspects of her self identity which left her feeling very frustrated and negative about herself, vividly illustrating the uncomfortable emotions generated in living up to the lofty demands of the social identity of manager. Further, her account revealed that 
after initially 'beating herself up' and questioning her suitability for the role, she was in time able to involve others in her identity work which turned attention away from internal self inadequacies outward to issues arising from expectations of the role:

"I went to see one of my colleagues and said 'these are the things that I am experiencing, is it just me, am I just the stupid one?' And he said, 'no, I have similar issues'. And I said 'we need to do something about this, things are ridiculous, they are not working and I am going to get very frustrated and I am going to end up just jacking it in if I am not careful'. And it was really interesting because it takes one person to open up and you find that lots of other people are in the same situation but nobody wants to take that first step”. [Trading Director, female, age 37]

This shift in focus in her identity work is important given that her frustration left her contemplating 'jacking it in' and thus rejecting the managerial identity completely. However, as she also indicates this movement was somewhat difficult since paradoxically the expectations of the managerial identity mean it is threatening for managers to ask for help. Indeed, another participant highlighted that the manager risks being 'thought a fool' if they ask questions:

"I was given the commercial manager's job and very quickly found myself extremely ineffectual in that post and struggled with it but I am not the sort of person who can let things go, I have to see something through to the end, I can't just throw my hands up and say 'I can't do this'. That affected my health because I was going into work at six o'clock in the morning and not going home til midnight, getting four hours sleep and then doing it all again, six, seven days a week. Eventually I did have to stand 
back and say 'I can't do this on my own, I need some expertise'..... I think actually that is a big problem in British management, people are scared to ask because they'll be thought a fool or well you are a manager why don't you know that?" [Business Development Manager, male, age 41]

The account draws attention to the private difficulties experienced in working on the identity of manager. Here, the social identity of manager as 'one who knows' interacts with the self identity of the 'sort of person who can't let things go' to generate serious consequences for the individual's health. The expectations of the managerial role to know appear to make it difficult for managers to ask for help, it is not the done thing (Schein, 1993) which makes for emotionally charged identity work where managers feel scared to speak up.

\section{It is almost like being an actor}

The silencing of the emotional tensions of identity work meant that managers often engaged in significant emotional labour (Hoschild, 1983) working to display an identity consistent with accepted notions of social identity of manager. Whilst the emotional labour of service workers has long been recognised, in the case of the manager it is rarely acknowledged.

"I can't believe I am saying this but as a manager of a big team, you have to put on this, it is almost like being an actor, isn't it to a certain extent? You play the audience, depending on who they are. I know this is against what I am supposed to be saying but I guess I always feel half the time, I am pretending, putting on a face that isn't the 
real me. Isn't what I talk about when I get home or what I do. And it is quite a relief to go 'phew, I don't have to worry or think about anybody else'”. [Communications Manager, female, age 46]

The almost confessional account highlights the uncomfortable negotiation between the 'real me' or private identity and 'what I am supposed to be' or the social identity of manager. Working on 'being a manager' is thus seen to involve an act or pretence and is akin to the observation in Costas and Fleming's (2009) study where managing is likened to the wearing of a mask which is returned at the end of the day. Similarly, the account suggests a sharp distinction between a work identity which generates considerable worry and a home identity which provides much yearned for relief. Others also highlighted the negative emotions created in working between the social identity of manager and self identity:

"It is the fact that you have people that are so reliant upon what you do, the way you behave as a manager is so important to the people that report into you. And the whole role model point of view, I find quite stressful because lots of the time I am having to go against the way I would like to be naturally" [Training Services Manager, male age 56]

This quote illustrates the stress experienced in working on the 'role model' aspect of managerial identity, an identity which is at odds with how one would like to be 'naturally' or privately. Furthermore, the stress of the emotional labour of managerial identity work, for some, in time stimulated a questioning of the managerial identity. 


\section{I have let myself off the hook}

Consistent with the processual understanding adopted, the interviews demonstrated that becoming a manager was never complete. In particular, the accounts provided by those who were in the later stages of their career and those who had since left formal managerial positions were especially insightful. As the quotation below describes, even late in the career, the struggles of identity work persisted:

"If I had my time again, I would stay as far away from management as possible but I came from a generation where promotion within a technical environment always came to an end, and that people from then on in were promoted to a managerial grade, and if you had not really achieved some sort of managerial position then you had not really made it, and I think I always had this ambition to be the manager. But lots of my character doesn't suit being a manager and I don't think I would go into management if I had my time again” [Training Services Manager, male, age 56]

It is evident from this account that even after years of working on the identity of manager, the individual still experiences considerable unease. His description indicates that whilst initially motivated by the symbolic success of the managerial role, to be a manager is to have 'made it'; over time he has learnt that aspects of his self identity were not well matched with other important aspects of the position. The evolving mismatch thus raises serious questions for him regarding his suitability to be a manager. This reveals the emergent and under acknowledged identity struggles that follow from seductive narratives which equate the managerial position with status and success. Whilst individuals might feel well matched to the career success that 
managerial positions imply, measuring up to other aspects of being manager are far more problematic. Indeed, negotiating the heavy expectations of the managerial identity for some continued even after leaving formal managerial positions:

"In particular, now that I am talking this through, the most significant thing was not feeling guilt ridden about things that didn't work, that I didn't take that all on my own shoulders. I now realise that things are that complicated, they involve that many people, the way that things change cannot be solely attributable to one individual. Therefore I have let myself off the hook”. [Sales and Marketing Director, male, age 41]

The account reports the significant guilt associated with not measuring up to the notion that as a manager one should always be successful, further highlighting the uncomfortable negotiation between social and self identities. Of note, after some time away from his managerial position he is still working on reconciling the guilt evoked in his identity work. Through the eventual challenging of what it means to be a manager and recognition of the limits of a manager's control, he has now "let himself off the hook" but as his comment suggests this has been a long and painful process.

\section{Discussion and Implications}

This study provides a contribution to theoretical understandings of identity work and perhaps more importantly, to management education. Turning first to the theoretical contribution and responding to calls from Sturdy et al., (2006), the work demonstrates the centrality of emotions to identity work processes. Specifically, it builds on 
Watson's (2008) model of managerial identity work to show how attempts to reconcile social and self identities generate considerable emotion and importantly that this is integral to developing a workable self identity. The work has shown how demanding social identities of manager make for a difficult identity work process where individuals struggle to come to terms with expectations of how one ought to be as a manager. This creates dissonance in the identity project which in practice means individuals experience significant anxiety, guilt, frustration and worry. Moreover, these emotional responses inform and are critical to ongoing identity work; the accounts have shown how individuals play through these to fashion a viable identity. Identity work then is a felt process where our emotions cannot be separated from who we are or who we might become. As Cunliffe and Coupland (2012: 69) contend "we are our bodies", and as seen here our emotions are fundamental to making ourselves.

This centrality of emotion to our identity work suggests the importance of its open and serious exploration. However, the work here also demonstrates that in the case of the manager, dominant discourses prevent the open exploration of emotion so integral to their identity work which makes the process of becoming manager more difficult. In this way, the study extends critical discussions of grandiose managerial discourse (Kerfoot and Knights, 1998; Willmott, 1984) in illustrating how this is mobilised by managers- it both creates and denies the uncomfortable emotions of identity work and sets in place a spiral of silence (Bowen and Blackmon, 2003). Indeed, the work shows the endurance of the emotional struggles of managerial identity work. Whilst becoming a manager is never complete (Parker, 2004); the degree of emotional discomfort reported by this sample of experienced MBA holding managers is surprising. Of concern, the analysis suggests that in dealing with these uncomfortable 
emotions, managers first turn attention inwards challenging aspects of self identity. This can be a destructive process where the individual comprehends the emotional response as a sign of personal identity weakness. However, the analysis also indicates in time identity work can turn outwards if individuals can work with the emotional response in opening up to others to question accepted understandings of notions of manager. This is consistent with Warhurst's (2011:275) "more optimistic, less deterministic" perspective which suggests managers are not "discursively deceived demons". The work therefore shows how emotional responses play into the making of ourselves, presenting both challenges and opportunities for who we might be. Crucially in the case of the manager, the voicing of emotional responses offers possibilities for more realistic and helpful forms of identity work. Yet the accounts also highlight the immense difficulties managers face in working with emotions to question prevailing dominant managerial discourse- perhaps not least because such discourse suggests managers have answers not questions.

One arena where managers are permitted to ask questions is the management classroom and accordingly I now turn to the implications for management education. Consistent with recent understandings of the business school as a holding environment for identity work (Petriglieri and Petriglieri, 2010), it is suggested that management education provides an important space which can facilitate a questioning of accepted understandings of notions of manager to allow for possibilities for more helpful identity work for managers. Whilst recognising that the space provided by management education is not without its own tensions (Reedy, 2003), the literature suggests it can offer a 'safe' space for identity work. As Ford et al (2010:S75) observe "it is with fellow students that the rational, non-emotional, super-human façade is 
allowed to slip". However, whilst the conditions might be ripe for more realistic identity work, to date these have not been sufficiently recognised by educators. What is more, educators are often complicit in reinforcing dominant managerial discourses (Vidaillet and Vignon, 2010).

Critical analyses of management education highlight the ways in which it is guilty of promoting and reinforcing managerial discourse. Chia and Holt (2008) and Ghoshal (2005) for example, highlight how an over emphasis upon scientific rigour avoids the complexities of the art of management practice. As Chia and Holt (2008: 476) contend this "unwittingly filters out the predicaments, the intractable problems, the agonising over and the sleepless nights that characterise the actual lived world of management practitioners". Similarly, Simpson (2007: 184) argues that this emphasis reinforces and maintains "a masculine way of organising and seeing the world" which is "out of touch with the needs of modern management". Arguably then management education in its maintenance of dominant managerial discourse plays a part in silencing the struggles of identity work surfaced here. Put differently, our avoidance of the complexities of management contributes to the 'disappearance' (Fletcher, 1998) of the struggles of identity work.

This avoidance may in part reflect the way in which dominant managerial discourse informs our identity as academics. A reliance on scientific rigour provides the possibility (albeit illusory) of offering expertise and solutions to managerial troubles (Grey, 2004). A turn to the complexities of management practice might be seen as a threat to our expert identity as one who provides answers. Currently then, management education often constrains rather than enables managers' identity work. 
It follows that management education needs to identify ways in which it can be more helpful to managers' identity work. Indeed, given the prevalence of concealed struggles found here, management education would be providing a disservice to its students in continuing to collude in their silencing. A starting point for enhanced input into managerial identity work is material which provides insight into the lived experiences of managers to provide alternative discursive resources. As Grey (2007) argues much of what we currently draw on is somewhat lacking. Indeed, Ford and Harding (2003) bemoan the production of academic papers focusing on the rational which contribute to the gulf between the rhetoric in most management texts and the exigencies of managerial life noted by Sayles (1989). The accounts here which reveal a level of humility and honesty that is typically quietened provide one modest offering.

Moreover, the humility and honesty revealed offers a connectedness and evocativeness which Chia and Holt (2008) contend is an overlooked but crucial aspect of management education, and is especially important in facilitating identity work. As Sparkes (2007) highlights, work which resonates with others provides possibilities for becoming. At a basic level, plausibly the resonance of the struggles of identity work as illustrated in the accounts here can be of personal benefit in helping managers to cope better (Wicks and Freeman, 1998). This might seem somewhat unremarkable but given that struggles are typically silenced their articulation is seen as important. Humphreys (2005:81) in revealing his own struggles of academic identity work contended that "it would have been helpful if someone had done this for me" and that he needed "evidence that other academics were also human beings with their own 
frailties". Whilst this relates to identity work involving a different occupation, the demands of expert identity are similar and the sentiments of sharing are equally applicable to managers. As Hill (1992) identified, "managers were as desperate for help in managing the (new) position's emotions and stresses as for help in making correct decisions about specific business problems". It is suggested that the empirical material presented here can be used in the management classroom to generate discussion around ongoing identity work struggles and to allow individuals to disclose their own insecurities.

In turn, this disclosure also provides possibilities for more realistic identity work. As Mischenko (2005) observes, sharing opens up possibilities for alternative ways of being. In particular, working with the unpleasant emotions generated such as anxiety and guilt can stimulate a questioning of accepted notions of what it means to be a manager, inviting possibilities for new knowledge and action (Cunliffe, 2002). Put differently, the assertion here is not concerned with helping managers to better contain their emotions but rather to use these in constructive ways to question their practice. Emotions can stimulate an acknowledgment of the often unrealistic demands placed on a manager and recognition that first and foremost, they too are human beings. The role of the management educator then is more akin to a facilitator who aids managers in this questioning process to develop their 'expertise in not knowing' (Raab, 1997).

In helping managers to explore their unknowingness, it is not suggested that managers can simply reject common understandings of what it means to be a manager, individuals are far more constrained in their agency than this. However, it can serve to 
recognise the limits of available managerial identities, for example the impossibility of a manager as one who has total control and knows everything. Acknowledging these limitations provides for identity work which "encourages a degree of humility about what management and managers can do" or indeed be (Brocklehurst et al, 2007:386). This offers possibilities for identity work which is more honest and more realistic (cf Grey, 2007) and ultimately more productive. Furthermore, if sufficient individuals engage in such a process, over time it might be possible that accepted notions of manager may evolve to include a greater degree of humility and vulnerability (cf Blenkinsopp, 2007).

In conclusion, it has been proposed that managerial identity work is constrained by available social identities of manager which makes for an often uncomfortable and difficult process of becoming a manager where the individual struggles to live up to idealised notions of managerial work. It is suggested that more realistic and helpful managerial identity work for individuals can be facilitated by making alternative understandings of 'manager' available. This work contributes to this process by surfacing silenced uncomfortable struggles of managerial identity work to demonstrate the centrality of emotions to processes of managerial becoming. It is in paying attention to these emotions that management education can help individuals in considering the limitations of what managers can be. In so doing, it would avoid a continuation of its current role in colluding in their silencing. Finally, it is acknowledged that issues of transferability are raised as the data is drawn from a small cross sectional sample of UK managers. However, it is suggested that the surfaced struggles may resonate with managers in other contexts. It is for future 
research to establish how these play out in different organisational and cultural settings. 


\section{References}

Alvesson, M and Willmott, H (2002) Identity regulation as organizational control: producing the appropriate individual. Journal of Management Studies 39 (5): 619644.

Alvesson, M, Ashcraft, KL and Thomas, R (2008) Identity matters: reflections on the construction of identity scholarship in organization studies. Organization 15 (1): 5-28.

Ashforth, B (1998) Becoming: How does the process of identification unfold? In: Whetten, D and Godfrey, P (eds.) Identity in Organisations: Developing Theory through Conversations. Thousand Oaks, CA: Sage, 213-22

Ashforth, B and Humphrey, RH (1993) Emotional labor in service roles: the influence of identity. Academy of Management Review 181 88-115.

Barley, SR and Kunda, G (2001) Bringing work back in. Organization Science 12 (1): 76-95.

Berger, PL and Luckmann, T (1966) The Social Construction of Reality, London: Penguin

Blenkinsopp, J (2007) Emotion in managerial careers. Paper presented to Academy of Management Meeting. Philadelphia, August $3^{\text {rd }}-8^{\text {th }}$. 
Bono, JE and Vey, MA (2005) Toward understanding emotional management at work: a quantitative review of emotional labor research. In: Hartel, CE, Zerbe, WJ and Ashkanasy, N (eds) Emotions in Organizational Behavior. Lawrence Erlbaum Associates: Mahwah, NJ, 213-33.

Bowen, F and Blackmon, K (2003) Spirals of Silence: The Dynamic Effects of Diversity on Organizational Voice. Journal of Management Studies, 40 (6): 13931417.

Brocklehurst, M, Sturdy, A, Winstanley, D and Driver, M (2007). Introduction. Whither the MBA? Factions, Fault lines and the future. Management Learning 38 (4): 379-388.

Broom, A, Hand, K and Tovey, P (2009) The role of gender, environment and individual biography in shaping qualitative research data. International Journal of Social Research Methodology 12 (1): 51-65.

Brotheridge, CM and Lee, RT (2008) The emotions of managing: an introduction to the special issue. Journal of Managerial Psychology 23 (2): 108-117.

Bruner, J. (1990) Acts of Meaning. Cambridge, MA: Harvard University Press.

Chia, R and Holt R (2008) The nature of knowledge in business schools. Academy of Management Learning and Education. 7 (4): 471-486. 
Clarke, CA, Brown, AD and Hope-Hailey, V (2009) Working identities? Antagonistic discursive resources and managerial identity. Human Relations 62 (3): 323-352.

Clarke, C, Hope-Hailey, V and Kelliher, C (2007) Being real or really being someone else? Change, managers and emotion work. European Management Journal 25 (2): 92-103.

Collinson, D (2003) Identities and insecurities: Selves at Work. Organization 10 (3): 475-96.

Costas, J and Fleming, P (2009) Beyond dis-identification: A discursive approach to self alienation in contemporary organizations. Human Relations 62 (3): 353-378.

Cunliffe, A (2002) Reflexive Dialogical Practice in Management Learning. Management Learning 33 (1): 35-61.

Cunliffe, A and Coupland, C (2012) From hero to villain to hero: making experience sensible through embodied narrative sensemaking. Human Relations, 65 (1): 63-88

Du Gay, P, Salaman, G and Rees, B (1996) The conduct of management and the management of conduct: contemporary managerial discourse and the constitution of the 'competent' manager. Journal of Management Studies 33 (3): 263-282. 
Elsbach, KD (1999) An expanded model of organizational identification. In Sutton, RI and Staw, B (eds.), Research in Organizational Behaviour, Volume 21. Stamford: JAI Press, 163-200.

Fletcher, J (1998) Relational practice: A feminist reconstruction of work. Journal of Management Inquiry 7: 163-88.

Fineman, S (1993) Emotion in Organizations. London: Sage.

Ford, J, Harding, N and Learmonth, M (2010) Who is it that would make Business Schools more critical? Critical Reflections on Critical Management Studies. British Journal of Management 21: S71-81.

Ford, J and Harding, N (2007) Move over managers: We are all leaders now. Management Learning 38 (5): 475-493.

Ford, J and Harding, N (2003) Invoking Satan or the ethics of the employment contract. Journal of Management Studies 40 (5): 1131-1150.

Foucault, M. (1980). Power/Knowledge: Selected Interviews and Other Writings 1972-77 (ed. C. Gordon). Harlow: Pearson.

Fulop, L, Linstead, S, Lilley, S and Clarke, R (2009) Decision making in organizations. In Linstead, S, Fulop, L and Lilley, S (eds.), Management and Organization, A Critical Text, $2^{\text {nd }}$ Edition. Basingstoke: Palgrave 667-708. 
Gabriel, Y (1999) Beyond happy families: a critical re-evaluation of the controlresistance-identity triangle. Human Relations 52 (2): 179-203.

Ghoshal, S. (2005) Bad management theories are destroying good management. Academy of Management Learning and Education, 4 (1): 75-91.

Goffman, E (1967) Interaction Ritual. New York: Aldine.

Grey, C. (2004) 'Reinventing Business Schools: The Contribution of Critical Management Education', Academy of Management Learning and Education, 3 (2): 178-186.

Grey, C (2007) A Very Short, Fairly Interesting and Reasonably Cheap Book about Studying Organizations. London: Sage.

Hill, LA (1992) Becoming a Manager. Mastery of a New Identity. Boston, MA: Harvard Business School Press.

Hoschild, AR (1983) The Managed Heart: Commercialization of Human Feeling. London: University of California Press.

Humphrey, RH, Pollack, JM and Hawver, T (2008) Leading with emotional labour. Journal of Managerial Psychology 23 (2): 151-68. 
Humphreys, M (2005) Getting personal: Reflexivity and autoethnographic vignettes. Qualitative Inquiry 11 (6): 840-860.

Ibarra, H (1999) Provisional selves: experimenting with image and identity in professional adaptation. Administrative Science Quarterly 44: 764-91.

Jackall, R (1988) Moral Mazes: The World of Corporate Managers, New York: Oxford University Press.

Jenkins, R (1996). Social Identity. London: Routledge.

Kerfoot, D and Knights, D (1998) Managing masculinity in contemporary organizational life: A 'Man'agerial project'. Organization 5 (1): 7-26.

Knights, D and Willmott, H (1989) Power and subjectivity at work, Sociology, 23: $535-58$

Knights, D and Vurdubakis, T (1994). Foucault, power and all that. In: Jermier, J, Knights, D and Nord, WN (eds) Resistance and Power in Organizations. London: Routledge.

Meindl, JR, Ehrlich, SB and Dukerich, JM (1985) The romance of leadership. Administrative Science Quarterly 30: 78-102. 
Mischenko, J (2005) Exhausting management work: conflicting identities. Journal of Health Organization and Management 19 (3): 204-218.

Mumby, DK and Chair, R. (1997) Organisational discourse. In van Dijk, TA (ed) Discourse as Structure and Process, Volume 2. London: Sage.

Ogbonna, E and Harris, LC (2004) Work intensification and emotional labour among UK university lecturers: An exploratory study. Organization Studies 25 (7): 11851203.

Parker, M (2004) Becoming manager or the werewolf looks anxiously in the mirror, checking for unusual facial hair. Management Learning 35 (1): 45-59.

Parkin, W (1993) The public and the private: Gender, sexuality and emotion. In: Fineman, S. (ed) Emotion in Organizations. London: Sage, 167-89

Petriglieri, GP and Petriglieri, JL (2010) Identity workspaces: the case of business schools. Academy of Management Learning and Education 9 (1): 44-60.

Raab, N (1997) Becoming an expert in not knowing. Reframing teacher as consultant. Management Learning 28 (2): 161-175.

Reedy, P. (2003). Together we stand? An investigation into the concept of solidarity in management education. Management Learning, 34 (1): 91-109. 
Reedy, P (2009) The Manager's Tale. Stories of Managerial Identity. Farnham: Ashgate.

Ritchie, J and Spencer, L (1994) Qualitative data analysis for applied policy research. In Bryman, A and Burgess RG (Eds.) Analyzing Qualitative Data. London: Routledge.

Rost, JC (1991) Leadership for the $21^{\text {st }}$ Century. New York: Praeger.

Sayles, LR (1989) Leadership: Managing in Real Organizations (2nd ed.). McGrawHill.

Schein, EH (1993). On dialogue, culture, and organizational learning. Organizational Dynamics, 22 (2): 40-51.

Schwandt, TA (1994) Constructivist, interpretivist approaches to human inquiry. In: Denzin, NK and Lincoln, YS (eds.), Handbook of Qualitative Research. Thousand Oaks, CA: Sage, 118-137.

Simpson, R (2007) Masculinity and management education: Feminizing the MBA. Academy of Management Learning and Education 5 (2): 182-193.

Sims, D (2003) Between the millstones: a narrative account of the vulnerability of middle managers' storytelling. Human Relations 56 (10): 1195-211. 
Somers, MR (1994) The narrative construction of identity: a relational and network approach. Theory and Society, 23 605-649.

Sparkes, A (2007) Embodiment, academics, and the audit culture: a story seeking consideration. Qualitative Research 7 (4): 521-550.

Strauss, A and Corbin, J (1998) Basics of Qualitative Research. Techniques and Procedures for Developing Grounded Theory, $2^{\text {nd }}$ Edition. London: Sage.

Sturdy, A, Brocklehurst, M, Winstanley, D and Littlejohns, M. (2006) Management as a (self) confidence trick: management ideas, education and identity work. Organization 13 (6): 841-860.

Sveningsson, S and Alvesson, M (2003) Managing managerial identities: Organizational fragmentation, discourse and identity struggle. Human Relations 56 (10): 1163-1193.

Thomas, R and Linstead, A (2002) Losing the plot? Middle managers and Identity. Organization 9 (1): 1-93.

Vidaillet, B and Vignon, C (2010) Bringing back the subject into management education. Management Learning 41 (2): 221-241.

Vince, R (2001) Power and emotion in organizational learning. Human Relations, 54 (10): $1325-51$. 
Warhurst, R. (2011) Managers' practice and managers' learning as identity formation: Reassessing the MBA contribution. Management Learning 42 (3): 261-278.

Watson, TJ (2001a) In Search of Management: Culture, Chaos and Control in Managerial Work. London: Thomson.

Watson, TJ (2001b) The Emergent Manager and the Process of Management Prelearning. Management Learning 32 (2): 221-235.

Watson, TJ (2002) Organising and Managing Work. Harlow: Pearson.

Watson, TJ (2005) Organização e trabalho em transição: da lógica "sistêmicocontroladora" à "lógica "processual-relacional. Revista de Administração de Empresas 45 (1): 14-23.

Watson, TJ (2008) Managing identity: Identity work, personal predicaments and structural circumstances. Organization 15 (1): 121-143.

Wicks, AC and Freeman, RE (1998) Organization Studies and the new pragmatism: positivism, anti-positivism and the search for ethics. Organization Science 9 (2):12340.

Willmott, H. (1984) Images and ideals of managerial work: A critical examination of conceptual and empirical accounts. Journal of Management Studies, 21 (3): 349-368. 
Ybema, S, Keenoy, T, Oswick, C, Beverungen, A, Ellis, N and Sabelis, I (2009) Articulating identities. Human Relations 62 (3): 299-322. 